\title{
Assessment of deformations in mining areas using the Riegl VZ-400 terrestrial laser scanner
}

\author{
Dariusz Szwarkowski ${ }^{1 *}$, Magdalena Moskal $^{1}$ \\ ${ }^{1}$ Cracow University of Technology, Faculty of Civil Engineering, Krakow, Poland
}

\begin{abstract}
The article discusses the use of terrestrial laser scanning to assess deformations in mining areas. Using the terrestrial laser scanning Riegl VZ-400, control measurements within the historical location of the underground coal mine in Zabrze were made. Two laser scanning measurements were taken over the course of one year. The research made it possible to determine changes in surface deformation on the shallowly located mining excavations. Differences in the terrain may be due to subsidence associated with the influence of underground mining and pose a threat to the adjacent road infrastructure and structures.
\end{abstract}

Keywords: terrestrial laser scanning, ground deformation, USBC

\section{Introduction}

The urbanized areas of the Upper Silesian Coal Basin (USCB) are characterized by deformations resulting from underground coal mining. In order to verify its impact on the existing road infrastructure and buildings, the endangered areas should be subjected to continuous monitoring. Changes in the surface area caused by underground mining excavations may take place even after a long period of time after the mining ended. The most common form of assessment of changes occurring in the rock mass is the deformation of the surface layers of the ground and the deformations of the terrain.

There are several ways to determine the measure of deformation of subsurface layers, among others with the use of benchmarks, satellite, aerial (LIDAR) and ground remote sensing [1,2].

The paper described the RIEGL VZ-400 terrestrial laser scanner characterized by ease of use, independence of measurements over time and sufficient accuracy of results. Currently, terrestrial laser scanning is commonly used in applications in the reclamation of post-mining areas $[3,4]$. It is the most frequently used form of monitoring mining deformations.

The paper discusses the important topic of land deformation in post-mining, strongly urbanized areas. The subject of considerations is the area over a series of underground mining excavations in Upper Silesia. In order to determine the surface deformation there, two measurements were made using a terrestrial laser scanner at an interval of ca. one year .

* Corresponding author: dszwarkowski@pk.edu.pl 
In order to identify surface deformation changes, both surface images were compared. The measurements are aimed at determining the suitability of terrestrial laser scanning to recognize discontinuous surface deformations.

\section{Characteristics of the Riegl VZ-400 terrestrial laser scanner}

\subsection{Scanning mechanism}

The Riegl VZ-400 terrestrial laser scanner emits a narrow beam of infrared light during measurement. The device is equipped with a linear scanning mechanism, based on a multiangle mirror rotating at high speed, making it possible to obtain unidirectional parallel scanning lines. The polygonal rotating mirror reflects the laser beams in different directions, creating scan lines. Along with the linear scan movement, the optical head rotates while performing a frame scan of 360 degrees. The laser pulse is collimated by the optics forming the beam and then reflected by the facet of the polygon mirror to finally pass through the exit window of the beam. Along the way, the emitted laser pulse can hit one or several targets, inducing first or another reflected pulses. These reflected "echo" optical signals run back into the device, pass through the glass window, are reflected to the receiver optics through the mirror and focused on the receiver. The receiver converts optical signals into electrical ones, which are amplified and subsequently sampled and digitized in the process of converting analogue signals into digital ones. Digitized signals are transmitted to the controller to process the online waveform [5].

\subsection{Generating data in the receiver}

Figure 1 shows the output signal of the emitter. The first pulse on the left comes from the laser transmitter. Encountering an obstacle in the form of eg a tree, it is reflected, which results in a partial "dampening" of the amplitude of the output pulse, similarly in the case of the extreme signal on the right of Fig. 2.1, illustrating the impulse reflected from the roof.

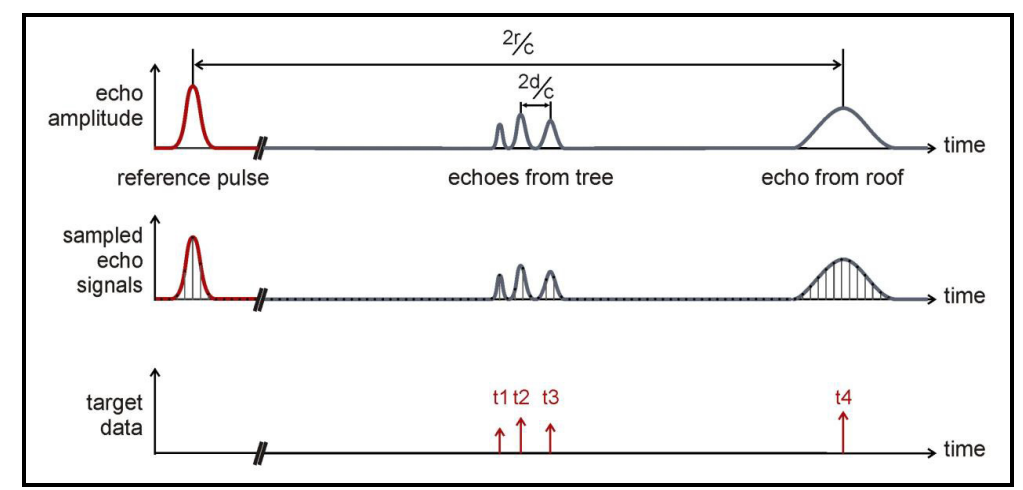

Fig. 1. Collection of reflected data by a measuring device [5].

The vertical lines in Fig. 1 correspond to the time at which the sample was taken. The scanner software analyzes the waveform. On this basis, calculations of the time positions of the reflected signals are performed, in this case as $t 1, . ., t 4$, for subsequent objects $1, \ldots, 4$. Multiplying the obtained time values by the known speed of light, the required range of the object is obtained for the four targets. The results regarding the range of objects (beam angle, date of measurement) are stored in the set of output data. 


\subsection{Measurement errors in scanning}

The basic objective of terrestrial laser scanner research is to obtain an accurate threedimensional image of the measured area. An important role in distorting the output image is played by the atmospheric conditions that can significantly affect the result of scans. Measurements with a terrestrial laser scanner during precipitation should be avoided beause the scan is characterized by a huge amount of interference in the course of the point cloud which also comprises, apart from the scanned objects and terrain, very small droplets of atmospheric precipitation. A big difficulty durning data processing from the obtained point cloud are areas characterized by a large amount of vegetation and tree stands, without characteristic permanent objects. The creation of scans on the basis of a point cloud created as a record of the history of changes in the position of individual leaves, boughs of trees and shrubs causes significant simplifications in the course of the shape of the terrain surface. A disadvantage of a laser measurement is a huge amount of data obtained from individual measurements. This involves the need to transform the scans and select the area which is most desirable from the viewpoint of its use. A person who makes a terrain measurement with the use of a terrestrial laser scanner should take into account the factors which are described above and which have a significant effect on the accuracy of the surface area obtained.

\section{Research area}

The analyzed area is located in southern Poland, in the area of the Upper Silesian Coal Basin (USCB). It is characterized by the extraction of coal, zinc, lead, iron and silver deposits since early Middle Ages [6, 7, 8]. Due to the shallow extraction of coal, this area is particularly exposed to discontinuous deformations.

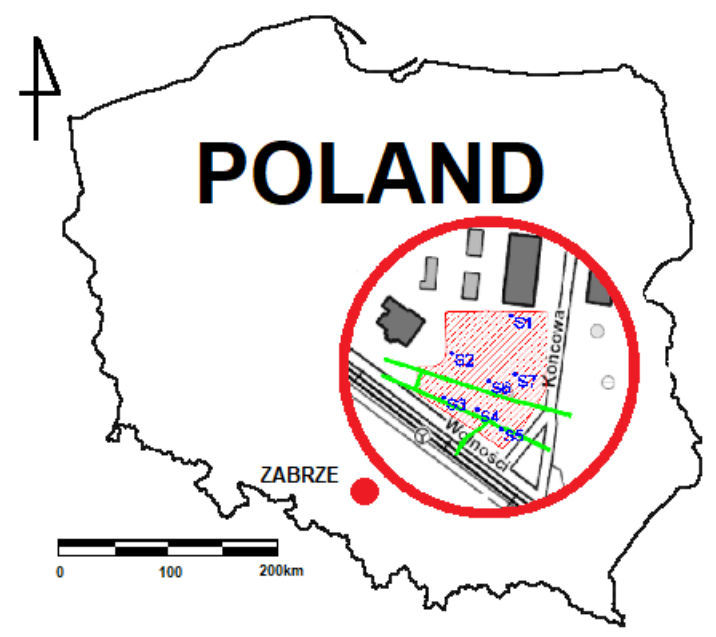

Fig. 2. Location of the research area with marked mining corridors.

The measurement with a terrestrial laser scanner was carried out in Zabrze, on plot No. 4962/42, at the intersection of Końcowa and Wolności Streets (Fig. 2). A city park with numerous trees and shrubs is located there. Below the discussed area, there is a historical string of underground mining excavation "No. 8 Pochhamer cut thru". It is marked white in Fig. 1. At a depth of about $32 \mathrm{~m}$, there are two parallel corridors located in Carboniferous seams. On the southern side of the excavation, a breakthrough was made in coal seams, 
connecting the two corridors. The described system of excavations is conducive to the formation of zones of weakening of rock mass and surface deformations of the area.

\section{Analysis and results}

The measurements carried out on 7 February 2018 are a continuation of the monitoring of the surface area conducted in previous years (i.e. 20 April 2015, 23 February 2017 and 1 June 2017) [8,9]. The current measurement was performed with the Riegl VZ-400 terrestrial laser scanner at seven measurement stands. As indicated in Fig. 1, the measuring points (S1-S7) are located in the immediate vicinity of an underground mining excavation. Two meaningful tests were used to analyse the ground deformation, carried out at one-year time interval (23 February 2017 and 7 February 2018). Measurements carried out at the same time of the year enable the elimination of factors distorting the measurement and also the subsequent interpretation of the results (among others, differences in flora). Figure 3 shows the initial image obtained after the registration of scans from individual measurement stands dated 7 February 2018.

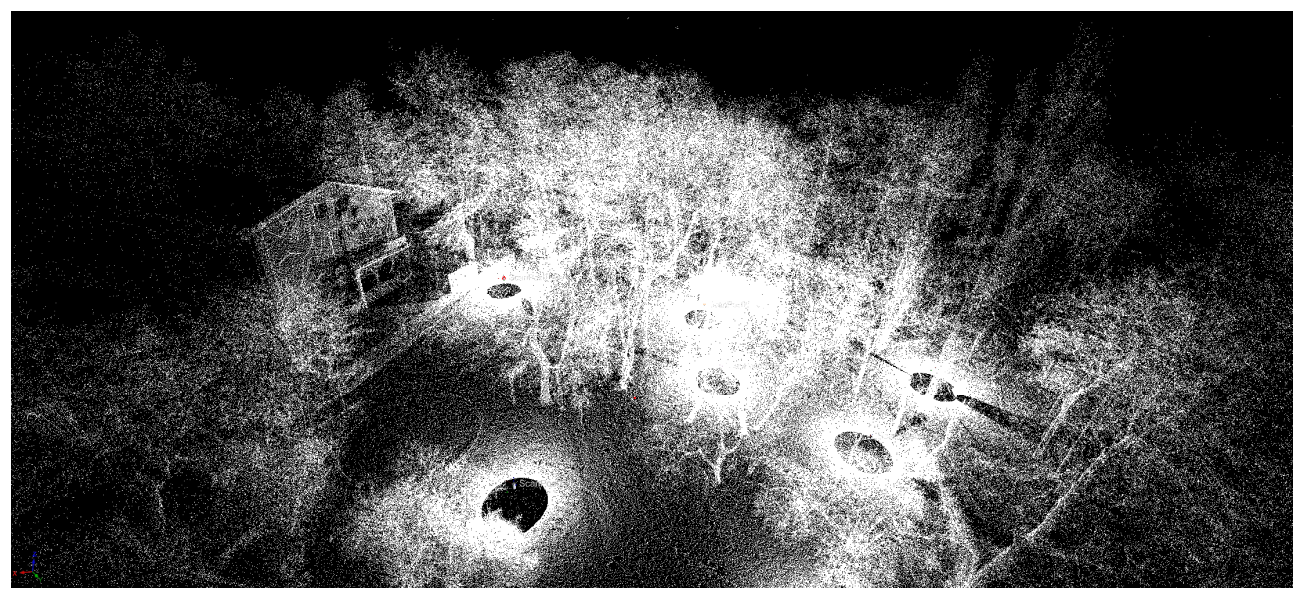

Fig. 3. Example of an image formed as a result of connecting scans from measurement stands in the research area (7.02.2018)

The analysis included a comparison of the land area obtained from both measurements in terms of its deformation and the location of their occurrence in relation to the location of underground mining excavations. Based on measurements made on 23 February 2017, a surface model was developed for Fig. 3. The terrain surface can be considered relatively flat, within the limits of 307.50 - 309.688 meters above sea level [9]. The largest deformation of the area can be seen in the area of the upper corridor of the mining excavation (Fig. 4). The zone that has settled is about $15 \mathrm{~m}$ long and $5 \mathrm{~m}$ wide. 


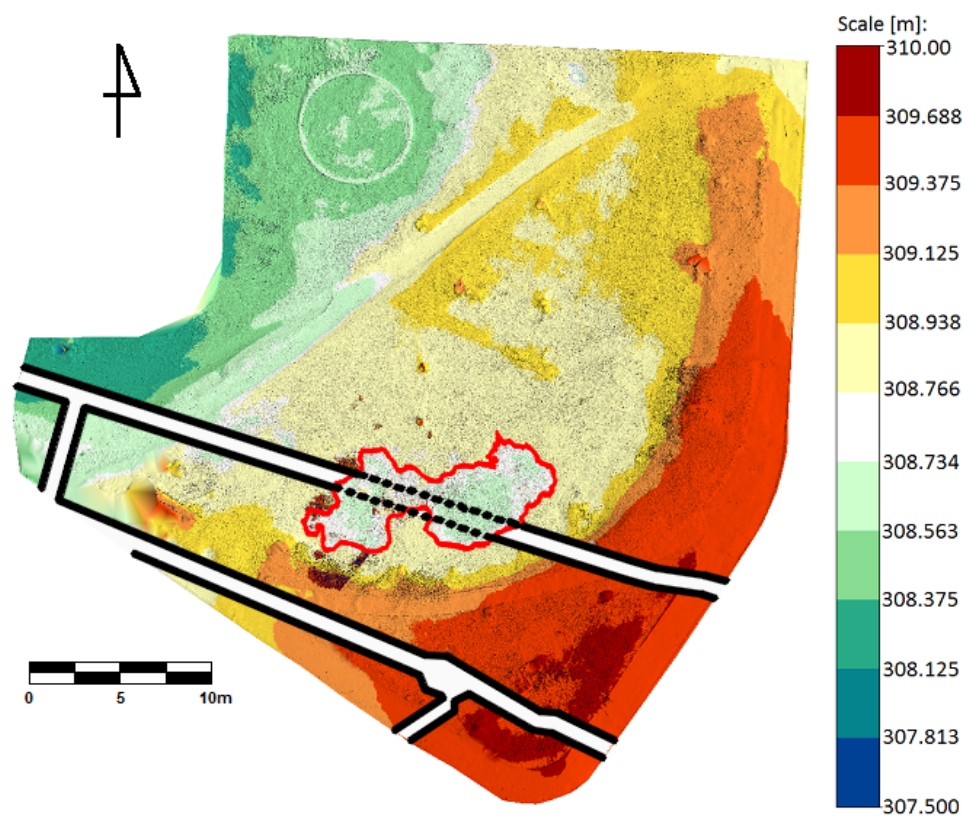

Fig. 4. Terrain surface model based on laser measurements of 23 February 2017

Another measurement of the analysed area was performed on 7 February 2018. The obtained terrain surface model is shown in Fig. 5.

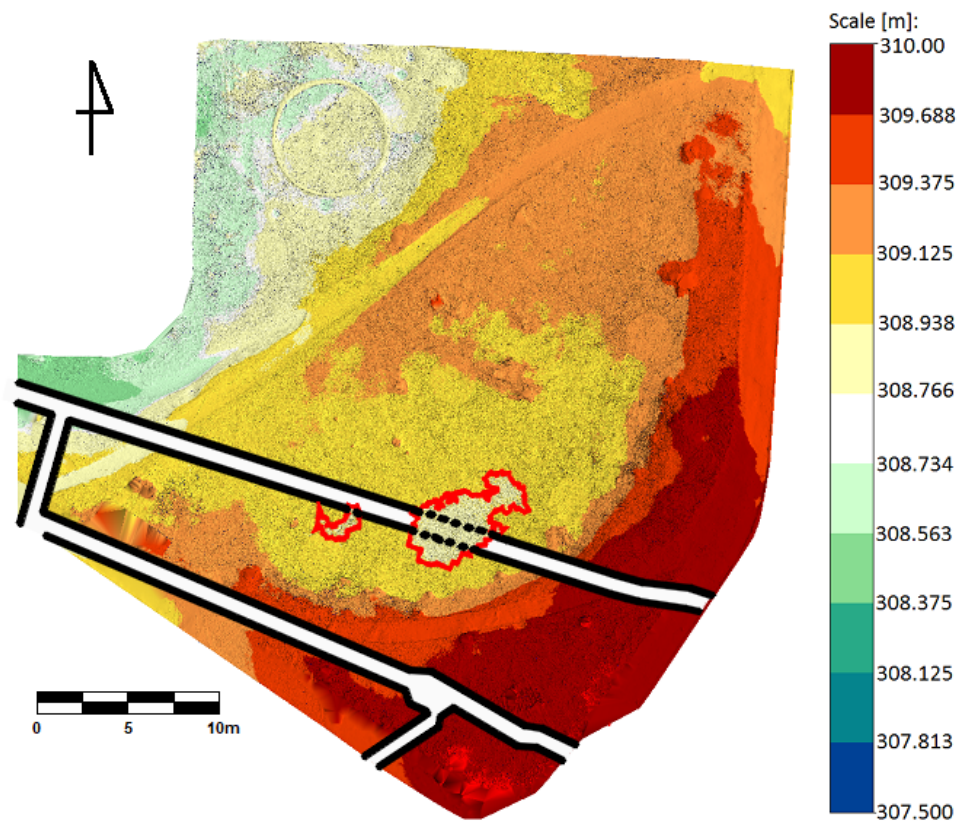

Fig. 5. Terrain surface model based on laser measurements of 7 February 2018.

The results are similar to those obtained in 2017. The visible local settlement of the area is located exactly in the same place. The area covered by the anomaly is smaller compared to the one obtained in 2017. 
Based on the measurements carried out on 23 February 2017 and 7 February 2018, a differential model of the analyzed area was made (Fig. 6).

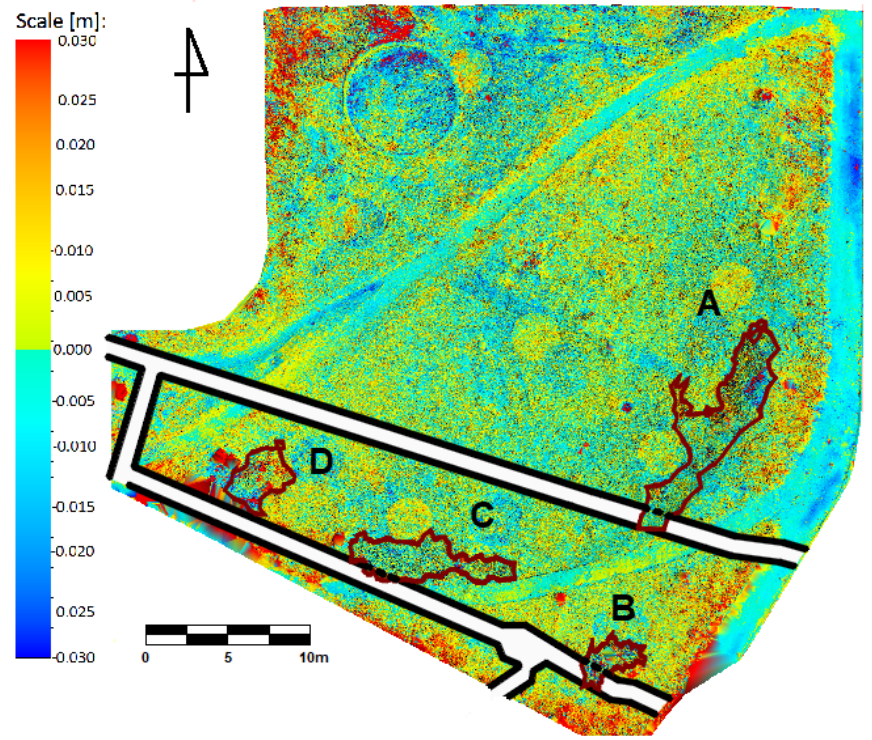

Fig. 6. Differential model of terrain surface based on laser measurements from February 23, 2017 and February 7, 2018

The calculated differences in coordinate values of the terrain surface are up to $3 \mathrm{~cm}$. In Fig. 6, we can see four zones [A, B, C, D] depicting possible terrain deformations related to the existence of underground mining excavations.

\section{Summary and conclusions}

The monitoring of analysed area by the RIEGL VZ-400 terrestrial laser scanner made it possible to determine surface deformations caused by underground mining from shallow historical mining excavations. Although hard coal is not extracted the analysed area anymore, slight deformations of the area still occur in the region of mining excavations. The monitoring carried out at a one-year interval enabled a reliable estimation of surface deformations of the area. They did not exceed $3 \mathrm{~cm}$ locally. Most likely, the resulting deformations are caused by subsidence of geological strata affected by the mining activity. The use of a terrestrial laser scanner made it possible to accurately reproduce the changes taking place in the spatial relief of the terrain. Due to the fast measurement time and the non-invasive monitoring, the terrestrial laser scanner measurement forms an important advantage of surface discontinuity testing. Its use is particularly beneficial in highly urbanized areas exposed to mining activities. Terrestrial laser scanner makes it possible to verify ground deformation and deformation of buildings which increase over time. This enables an assessment of the risk to the existing infrastructure and residents. 


\section{References}

1. Goszcz, Powstawanie zapadlisk i innych deformacji nieciągłych powierzchni na obszarach płytkiej eksploatacji górniczej. Mat. Konf. Szkoła Eksploatacji Podziemnej '96. CPPGSMiE PAN, Szczyrk, pp. 119-137 (1996)

2. M. Chudek, Geomechanika $\mathrm{z}$ podstawami ochrony środowiska górniczego i powierzchni terenu. Wyd. Politechniki Śl., Gliwice (2002)

3. Miłkowski, Z. Pilecki, K. Kłosek, M. Tondera, Autostrada A1 zaprojektowana na „dziurawym” podłożu, Cz. 1. Magazyn Autostrady: budownictwo drogowomostowe 3/2010, pp. 104-112 (2010)

4. Z. Pilecki, A. Kotyrba, Problematyka rozpoznania deformacji nieciągłych dla potrzeb projektowania konstrukcji drogowych na terenie płytkiej eksploatacji rud metali. Prace Naukowe GIG III/2007, pp. 379-392 (2007)

5. Riegl LMS, Oprogramowanie Systemowe i Przetwarzania Danych RiSCAN PRO dla skanerów laserowych 3D firmy RIEGL LMS. Austria (2009)

6. Z. Pilecki, A. Kotyrba, Problematyka rozpoznania deformacji nieciągłych dla potrzeb projektowania konstrukcji drogowych na terenie płytkiej eksploatacji rud metali. Prace Naukowe GIG III/2007, pp. 379-392 (2007)

7. Z. Pilecki, E. Pilecka, J. Pszonka, J. Stanisz, J. Morman, Zagrożenia deformacjami nieciągłymi na obszarze górniczym Jaworzno III, IGSMiE PAN, Kraków (2012)

8. Z. Pilecki, E. Popiołek, Wpływ eksploatacji rud na zagrożenie powierzchni deformacjami nieciągłymi i jego badanie za pomocą metod geofizycznych, Studia, Rozprawy, Monografie 84, IGSMiE PAN, Kraków (2000)

9. E. Pilecka, D. Szwarkowski, An application of the ground laser scanning to recognise terrain surface deformation over a shallowly located underground excavation, E3S Web of Conferences 24 (2017) 